\title{
Stosowanie ułatwień w opłacaniu składek na ubezpieczenia społeczne ze względu na tzw. stan finansów ubezpieczeń społecznych
}

\author{
Applying Facilitations in the Payment of Social Insurance \\ Contributions as a Result of the So-called State of Social \\ Insurance Finances
}

Streszczenie. Stosowanie ułatwień w opłacaniu składek na ubezpieczenia społeczne jest uzależnione m.in. od „stanu finansów ubezpieczeń społecznych”. Celem niniejszego artykułu jest określenie, czym jest „stan finansów ubezpieczeń społecznych”, brak jest bowiem opracowań w tym zakresie. Autor odnosi „stan finansów ubezpieczeń społecznych” do takich pojęć, jak: stan finansów publicznych i interes publiczny. Wskazuje, że „stan finansów ubezpieczeń społecznych” należy interpretować w kontekście finansów największego i najważniejszego z funduszy z zakresu ubezpieczeń społecznych, tj. Funduszu Ubezpieczeń Społecznych. Autor podkreśla, że o ile umorzenie składek realnie wpływa na finanse ubezpieczeń społecznych, o tyle odroczenie terminu płatności czy rozłożenie należności na raty, mają znaczenie symboliczne. 
Opracowanie kończą wnioski, z których wynika, że „stan finansów ubezpieczeń społecznych” musi być interpretowany w sposób dynamiczny: w zależności od rodzaju ułatwienia oraz sytuacji finansowej Funduszu Ubezpieczeń Społecznych.

Słowa kluczowe: finanse ubezpieczeń społecznych; Fundusz Ubezpieczeń Społecznych; składki na ubezpieczenia społeczne, ułatwienia w opłacaniu składek na ubezpieczenia społeczne.

\begin{abstract}
Applying facilitations in the payment of social insurance contributions is linked with, inter alia, the "state of social insurance finances". The article was written in order to elaborate upon the term "state of social insurance finances", as there is no literature on the subject. The author relates the term "state of social insurance finances" to such term as: state of public finances and public interest. It is indicated that the "state of social insurance finances" should be interpreted in the context of the finances of the largest and most significant fund of this type, the Social Insurance Fund. The author emphasizes that although remission of contribution payables has a tangible impact on social insurance finances, postponing payment or arrangement of payment in installments is of symbolic significance. The conclusions can lead to the assumption that the "state of social insurance finances" must be interpreted in a dynamic manner: depending on the types of facilitations and the financial situation of the Social Insurance Fund.
\end{abstract}

Keywords: social insurance finances; Social Insurance Fund; social insurance contributions; facilitation of payment of social insurance contributions.

\title{
1. Wprowadzenie
}

Ustawa z 13 października 1998 r. o systemie ubezpieczeń społecznych ${ }^{1}$ w art. 28-29 reguluje problematykę umorzenia należności z tytułu składek, odraczania terminu płatności oraz rozkładania należności na raty. Umorzenie, odraczanie i rozkładanie na raty należności z tytułu składek określa się jako „mechanizmy prawne ułatwiające zapłatę składki”2 czy

$1 \quad$ Tekst jedn. Dz.U. z 2009 r. Nr 205, poz. 1585 ze zm. (dalej również jako: ustawa systemowa, u.s.u.s.).

2 I. Jędrasik-Jankowska, Pojęcia i konstrukcje prawne ubezpieczenia społecznego, Warszawa 2010, s. 41. 
„mechanizmy ułatwiające płatnikowi zapłatę składki”3. W literaturze wskazuje się także, że odroczenie terminu płatności i rozłożenie na raty należności z tytułu składek to „ulgi” w opłacaniu składek, do których jednak zaliczyć nie można umorzenia należności z tytułu składek ${ }^{4}$. Odmienny pogląd zaprezentowany został w wyrokach WSA w Warszawie z dnia 23 marca 2006 r. $^{5}$ i z dnia 26 czerwca 2006 r. ${ }^{6}$, w których jako odrębne rodzaje ulg w spłaceniu należności, poza odroczeniem i rozłożeniem na raty, zaliczono także umorzenie należności z tytułu składek. Podobne stanowisko zajmuje J. Strusińska-Żukowska, wg której art. 29 ustawy systemowej „reguluje kolejne, po możliwości umorzenia, formy ulgi w spłacie należności z tytułu składek: odroczenie terminu płatności

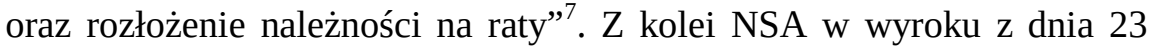
stycznia 2008 r. ${ }^{8}$ uznał, że u.s.u.s. „nie przewiduje możliwości zniwelowania istniejącego zadłużenia z tytułu nieopłaconych składek w postaci zastosowania tzw. ulgi. W stosunku do istniejących zaległych należności dłużnik może wnioskować o: 1) umorzenie przez Zakład w całości lub w części (art. 28 u.s.u.s.), 2) odroczenie terminu płatności należności z tytułu składek oraz rozłożenie należności na raty (art. 29 u.s.u.s.)”.

Na potrzeby niniejszego opracowania zasadne jest przyjęcie, że regulacje dotyczące umorzenia należności z tytułu składek, odraczania terminu płatności oraz rozkładania należności na raty mają na celu wprowadzenie ułatwień w opłacaniu składek dla płatników. Użycie określenia „ułatwienia” zgodne jest zatem z naturą i celem regulacji wprowadzających wskazane wyżej mechanizmy oraz oddaje ich istotę.

Ustawodawca określił przesłanki, które warunkują możliwość umorzenia należności z tytułu składek czy też odroczenia terminu płatności

3 I. Jędrasik-Jankowska, Ubezpieczenie emerytalne. Trzy filary, Warszawa 2001, s. 91; I. Jędrasik-Jankowska, Ubezpieczenie społeczne. Tom 1. Część ogólna, Warszawa 2003, s. 63.

4 Zob. szerzej: J. Wantoch-Rekowski, Składki na ubezpieczenie emerytalne. Konstrukcja i charakter prawny, Toruń 2005, s. 195-201.

5 III SA/Wa 3208/05, CBOSA.

6 III SA/Wa 1069/06, CBOSA.

7 J. Strusińska-Żukowska [w:] Ustawa o systemie ubezpieczeń społecznych. Komentarz, pod red. B. Gudowskiej i J. Strusińskiej-Żukowskiej, Warszawa 2011, s. 472.

8 II GSK 346/07, CBOSA. 
bądź rozłożenia należności na raty. I tak, zgodnie z art. 28 ust. 3a u.s.u.s., należności z tytułu składek na ubezpieczenia społeczne ubezpieczonych będących równocześnie płatnikami składek na te ubezpieczenia mogą być w uzasadnionych przypadkach umarzane pomimo braku ich całkowitej nieściągalności. W art. 28 ust. 3b ustawodawca wskazał, że minister właściwy do spraw zabezpieczenia społecznego określi, w drodze rozporządzenia, szczegółowe zasady umarzania, o którym mowa w ust. 3a, z uwzględnieniem przesłanek uzasadniających umorzenie, biorąc pod uwagę ważny interes osoby zobowiązanej do opłacenia należności z tytułu składek oraz „stan finansów ubezpieczeń społecznych”. Z kolei z art. 29 ust. 1 wynika, że ze względów gospodarczych lub innych przyczyn zasługujących na uwzględnienie Zakład może na wniosek dłużnika odroczyć termin płatności należności z tytułu składek oraz rozłożyć należność na raty, uwzględniając możliwości płatnicze dłużnika oraz „stan finansów ubezpieczeń społecznych”.

Stosowanie ułatwień w opłacaniu składek jest uzależnione m.in. od „stanu finansów ubezpieczeń społecznych”. O ile orzecznictwo i doktryna szeroko zajmują się interpretacją pojęć „ważny interes osoby zobowiązanej” czy „możliwości płatnicze dłużnika”, o tyle „stan finansów ubezpieczeń społecznych” jest marginalizowany. Celem niniejszego opracowania jest zatem określenie, czym jest „stan finansów ubezpieczeń społecznych".

\section{2. „Stan finansów ubezpieczeń społecznych” a stan finansów publicznych}

J. Strusińska-Żukowska wskazuje, że „Interes publiczny sprowadzający się do dbałości o stan finansów publicznych - finansów ubezpieczeń społecznych - nie powinien być rozumiany jako z zasady sprzeczny z ważnym interesem osoby zobowiązanej. Sytuacja, w której zapłata zaległości spowoduje jeszcze większą konieczność sięgania przez zobowiązaną, pozbawioną możliwości zaspokojenia swoich i swojej rodziny niezbędnych potrzeb materialnych, do środków pomocy państwa, nie jest zgodna 
z interesem obywatela, nie jest także zgodna z interesem publicznym"9 Takie stanowisko zaprezentowano również w orzecznictwie, na co wskazała J. Strusińska-Żukowska (wyrok WSA w Warszawie z 17 grudnia 2007 r. $^{10}$ ). Na wyrok WSA w Warszawie z 17 grudnia 2007 r. powoływano się później w innych wyrokach, cytując zwrot „interes publiczny sprowadzający się do dbałości o stan finansów publicznych - finansów ubezpieczeń społecznych”. Przykładowo wskazać można najnowsze orzeczenia: wyrok WSA w Lublinie z 14 lutego 2012 r. ${ }^{11}$, wyrok WSA w Poznaniu z 30 października 2012 r. ${ }^{12}$, wyrok WSA w Bydgoszczy z 12 grudnia 2012 r. $^{13}$, wyrok WSA w Lublinie z 7 lutego 2013 r. $^{14}$

W tym miejscu rodzi się pytanie, czy zasadne jest utożsamianie pojęcia „stan finansów ubezpieczeń społecznych” z pojęciem „stan finansów publicznych"?

Niewątpliwie pojęcie „finanse publiczne” to pojęcie szersze niż „finanse ubezpieczeń społecznych”. Ustawa z 30 czerwca 2005 r. o finansach publicznych ${ }^{15} \mathrm{w}$ art. 4 ust. 2 wskazywała, że sektor finansów publicznych dzieli się na trzy podsektory, a jednym z nich był podsektor ubezpieczeń społecznych, który obejmował Zakład Ubezpieczeń Społecznych, Kasę Rolniczego Ubezpieczenia Społecznego i zarządzane przez nie fundusze. ${ }^{16}$ Aktualna ustawa o finansach publicznych - z 27 sierpnia 2009 r. $^{17}$ - w art. 9 pkt 8 zalicza Zakład Ubezpieczeń Społecznych i zarządzane przez niego fundusze oraz Kasę Rolniczego Ubezpieczenia Społecznego i fundusze zarządzane przez Prezesa KRUS do sektora finansów publicznych.

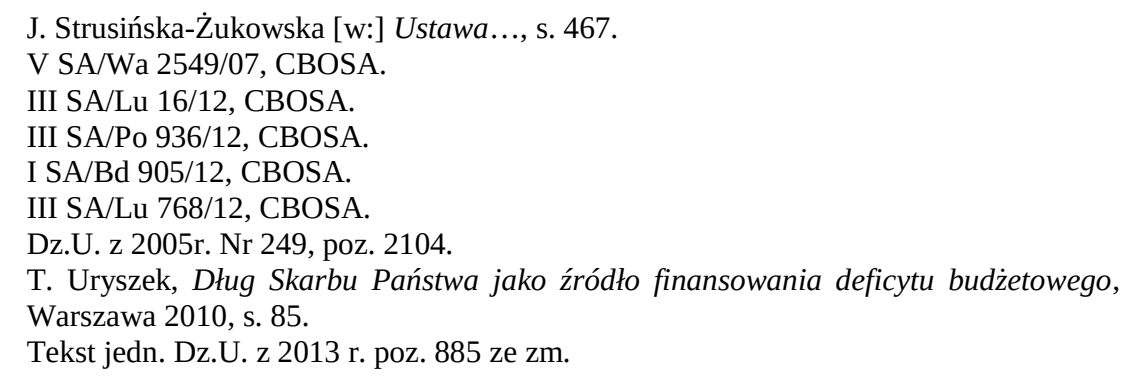


Należy wskazać, że podstawowym przychodem systemu finansowego ubezpieczeń społecznych są składki na ubezpieczenia społeczne, które są przeznaczane na wypłatę świadczeń ubezpieczeniowych. Finanse ubezpieczeń społecznych skoncentrowane są głównie w ramach Funduszu Ubezpieczeń Społecznych, którego dysponentem jest Zakład Ubezpieczeń Społecznych. FUS nie jest jednak funduszem w pełni autonomicznym, ponieważ jego przychody nie wystarczają na pokrycie wydatków na świadczenia, stąd konieczność (będąca pochodną gwarancyjnej funkcji państwa) kierowania dotacji z budżetu państwa. Wskazać również należy, że ze środków budżetowych (państwa i jednostek samorządu terytorialnego) finansowane są składki na ubezpieczenia społeczne - zwłaszcza w sytuacji, gdy płatnikiem składek są jednostki sektora finansów publicznych.

Nie wydaje się jednak trafne utożsamianie „stanu finansów ubezpieczeń społecznych” ze „stanem finansów publicznych”. Nie można przecież wykluczyć, że stan finansów ubezpieczeń społecznych będzie wskazywał na istnienie nadwyżek składek nad wydatkami na świadczenia, a jednocześnie stan finansów publicznych będzie zły (duży deficyt budżetowy, państwowy dług publiczny na poziomie przekraczającym 3/5 PKB), czy też sytuacji odwrotnej. Finanse ubezpieczeń społecznych można łączyć z finansami publicznymi, ale nie można ich utożsamiać.

\section{3. „Stan finansów ubezpieczeń społecznych” w świetle przepisów i orzecznictwa}

W zakresie umorzenia składek zwrot „stan finansów ubezpieczeń społecznych” pojawia się w przepisie zawierającym delegację ustawową do wydania rozporządzenia. Na podstawie art. 28 ust. 3b ustawy systemowej zostało wydane rozporządzenie Ministra Gospodarki, Pracy i Polityki Społecznej z 31 lipca 2003 r. w sprawie szczegółowych zasad umarzania należności z tytułu składek na ubezpieczenia społeczne ${ }^{18}$.

18 Dz.U. z 2003 r. Nr 141, poz. 1365. 
Określając szczegółowe zasady umarzania, minister został zobligowany do uwzględnienia przesłanek uzasadniających umorzenie, przy wzięciu pod uwagę ważnego interesu osoby zobowiązanej do opłacenia należności z tytułu składek oraz stanu finansów ubezpieczeń społecznych. W związku z tym w orzecznictwie zwrócono uwagę na to, że stan finansów ubezpieczeń społecznych uwzględniony został już na etapie formułowania przesłanek umorzenia zawartych w rozporządzeniu i przeciwstawianie interesu finansów ubezpieczeń społecznych interesom osoby zobowiązanej nie znajduje oparcia w przepisach. ${ }^{19}$ WSA w Szczecinie w wyroku z 4 marca $2009 \mathrm{r}^{20}{ }^{20}$ stwierdził wprost, że „zawarta w ustawie o systemie ubezpieczeń społecznych dyrektywa uwzględniania stanu finansów ubezpieczeń społecznych, jako jednej z przesłanek, obok ważnego interesu zobowiązanego, ustalenia szczegółowych zasad umarzania należności z tytułu składek na ubezpieczenie społeczne, zaadresowana została nie do organu orzekającego w indywidualnej sprawie, lecz do prawodawcy upoważnionego do określenia tych zasad i przez tego prawodawcę uwzględniona przy ich kształtowaniu".

W orzecznictwie można spotkać poglądy, wg których w przypadku umarzania należności z tytułu składek należy stosować art. 7 ustawy z 14 czerwca 1960 r. - Kodeks postępowania administracyjnego ${ }^{21}$ („W toku postępowania organy administracji publicznej stoją na straży praworządności, z urzędu lub na wniosek stron podejmują wszelkie czynności niezbędne do dokładnego wyjaśnienia stanu faktycznego oraz do załatwienia sprawy, mając na względzie interes społeczny i słuszny interes obywateli.”). Pogląd ten jednak nie jest trafny, ponieważ w sprawach dotyczących umorzeń (na podstawie art. 28 ust. 3a ustawy systemowej) przesłanki umorzenia w sposób szczegółowy określone są (a właściwie: powinny być), w wydanym na podstawie art. 28 ust. 3b ustawy systemowej rozporządzeniu Ministra Gospodarki, Pracy i Polityki Społecznej

\footnotetext{
19 Wyrok WSA w Warszawie z 27 września 2006 r., III SA/Wa 1761/06, CBOSA.

20 I SA/Sz 697/08, CBOSA.

21 Tekst jedn. Dz.U. z 2013 r. poz. 267.
} 
z 31 lipca 2003 r. w sprawie szczegółowych zasad umarzania należności z tytułu składek na ubezpieczenia społeczne ${ }^{22}$.

Zarówno delacja ustawowa, jak i samo rozporządzenie zostało poddane krytyce ${ }^{23}$. O ile w sposób szczegółowy (wręcz kazuistyczny) odniesiono się w tym rozporządzeniu do ważnego interesu osoby zobowiązanej, o tyle „stan finansów ubezpieczeń społecznych” całkowicie pominięto.

Przy umarzaniu należności z tytułu składek na ubezpieczenia społeczne w sposób nieuzasadniony utożsamia się stan finansów ubezpieczeń społecznych z interesem publicznym. NSA w wyroku z 20 marca 2007 r. ${ }^{24}$ zwrócił uwagę, że interes publiczny należy sprowadzić do interesu jednego z działów finansów publicznych, określanego jako stan finansów ubezpieczeń społecznych, który z zasady sprzeczny jest z interesem prywatnym, tj. ważnym interesem osoby zobowiązanej. Sąd ten przyjął, że „sytuacja, w której zapłata zaległości powoduje konieczność sięgania przez zobowiązanego, pozbawionego możliwości zaspokojenia swoich niezbędnych potrzeb materialnych, do środków pomocy państwa, nie jest bowiem zgodna z interesem tego obywatela, jednocześnie nie jest również zgodna z interesem publicznym",25.

O ile z ogólnospołecznego punktu widzenia zaprezentowana wyżej teza jest trafna, o tyle w odniesieniu do konkretnych regulacji dotyczących ułatwień w opłacaniu składek nie można się z nią zgodzić. Należy podkreślić, że Zakład Ubezpieczeń Społecznych, stosujący ułatwienia dla płatników składek, powinien uwzględniać sytuację finansową Funduszu

22 Tak również w wyroku NSA z 6 stycznia 2009 r. (II GSK 595/08, CBOSA) i wyroku NSA z 12 stycznia 2012 r. (II GSK 1416/10, CBOSA).

23 Zob. J. Wantoch-Rekowski, Umarzanie należności z tytułu składek na ubezpieczenia społeczne, „Praca i Zabezpieczenie Społeczne” 2004, nr 3, s. 36.

24 V SA/Wa 1559/07, CBOSA.

25 II GSK 345/06, CBOSA. Teza sformułowana przez NSA była następnie powoływana w późniejszych orzeczeniach sądów administracyjnych. Przykładowo można wskazać na wyrok NSA z 5 marca 2013 r. (II GSK 2270/11, CBOSA), wyrok NSA z 2 grudnia 2010 r. (II GSK 1036/09, CBOSA), wyrok NSA z 21 maja 2009 r. (II GSK 1045/08, CBOSA), wyrok WSA w Olsztynie z 27 czerwca 2013 r. (I SA/Ol 364/13, CBOSA), wyrok WSA w Warszawie z 26 marca 2013 r. (V SA/Wa 63/13, CBOSA), wyrok WSA w Opolu z 27 stycznia 2012 r. (I SA/Op 470/11, CBOSA), wyrok WSA w Olsztynie z 11 lutego 2009 r. (I SA/Ol 552/08, CBOSA), wyrok WSA w Warszawie z 17 grudnia 2007 r. (V SA/Wa 2549/07, CBOSA). 
Ubezpieczeń Społecznych. Ustawa systemowa nie stawia przez Zakładem zadania dbania o finanse budżetu państwa czy budżetów jednostek samorządu terytorialnego. Dyskusyjna jest zatem teza zaprezentowana przez WSA w Poznaniu w wyroku z 26 lutego 2013 r. ${ }^{26}$, że „przy podejmowaniu decyzji dotyczącej umorzenia należności z tytułu składek organ powinien ocenić sytuację skarżącego z uwzględnieniem ewentualnego powstania dalszych ciężarów dla państwa lub podmiotów samorządu terytorialnego, które będą zobowiązane do udzielenia zobowiązanemu pomocy”27.

W niektórych orzeczeniach sądy wskazują, że stosując ułatwienia w opłacaniu składek, należy brać pod uwagę interes publiczny, pod którym to pojęciem należy rozumieć stan finansów ubezpieczeń społecznych - tak np. NSA w wyroku z 29 maja 2012 r. ${ }^{28}$ czy WSA w Lublinie w wyroku z 4 grudnia $2012 \mathrm{r}^{29}$

\section{4. „Stan finansów ubezpieczeń społecznych” jako sytuacja finansowa Funduszu Ubezpieczeń Społecznych}

„Stan finansów ubezpieczeń społecznych” należy interpretować w kontekście sytuacji głównego funduszu z zakresu ubezpieczeń społecznych, tj. Funduszu Ubezpieczeń Społecznych, którego przychody (głównie: składki) pokrywają wydatki na świadczenia ubezpieczeniowe. W przypadku deficytu tego funduszu następuje finansowe zaangażowanie środ-

26 III SA/Po 774/12, CBOSA.

27 WSA w Łodzi w wyroku z 2 września 2010 r. (I SA/Łd 715/10, CBOSA) powołał stanowisko Zakładu, że „rozpatrując wniosek o umorzenie Zakład bierze pod uwagę nie tylko interes dłużnika, ale również funduszu ubezpieczeń społecznych. Z uwagi na szczególny zakres świadczonych usług i odpowiedzialność za środki wpływające do budżetu państwa Zakład zobowiązany jest do rozpatrywania tego typu spraw ze szczególną ostrożnością, bowiem przedmiotem podlegającym decyzji są należności publicznoprawne.” O ile zasadne jest powoływanie się przez Zakład na interes funduszu ubezpieczeniowego, o tyle argument o odpowiedzialności za środki wpływające do budżetu państwa jest nietrafny, gdyż rolą ZUS nie jest dbanie o stan budżetu państwa. Podobne stanowisko Zakładu przytoczono w wyroku WSA w Łodzi z 9 listopada 2010 r. (I SA/Łd 1085/10, CBOSA).

28 II GSK 589/11, CBOSA.

29 III SA/Lu 588/12, CBOSA. 
ków z budżetu państwa, przede wszystkim przekazywanych w formie dotacji. NSA w wyroku z 18 maja 2011 r. ${ }^{30}$ wskazał, że umorzenie należności z tytułu zaległych składek na ubezpieczenie społeczne ma charakter wyjątkowy i zarezerwowane jest dla sytuacji nadzwyczajnych, a umorzone składki w istocie pokrywają inni ubezpieczeni.

Trafnie orzekł WSA w Opolu w wyroku z 6 października 2010 r. ${ }^{31}$, że umorzenie zaległości powoduje bezpowrotną utratę dochodów Funduszu Ubezpieczeń Społecznych, co może negatywnie wpływać na stan finansów ubezpieczeń społecznych. ${ }^{32} \mathrm{Z}$ kolei WSA w Poznaniu w wyroku z 4 lipca 2012 r. ${ }^{33}$ wskazał, że ustawowym obowiązkiem ZUS jest dochodzenie należności, a „istotną granicę dla decyzji o umorzeniu należności z tytułu składek stanowi kolizja z interesem społecznym. Interes społeczny to bowiem obowiązek Zakładu do działania uwzględniającego interesy funduszy ubezpieczeniowych, którymi zarządza”34.

Należy podkreślić, że „stan finansów ubezpieczeń społecznych” nie jest możliwy do określenia jednorazowo, jest on zmienny w czasie, dlatego też przesłanki zastosowania ułatwień w opłacaniu składek powinny być rozpatrywane nie tylko w kontekście sytuacji finansowej płatnika, ale także w odniesieniu do bieżącego stanu finansów ubezpieczeń społecznych $^{35}$.

Zbyt daleko idące wnioski sformułował WSA w Gliwicach w wyroku z 15 maja 2009 r. ${ }^{36}$ Wprawdzie trafnie przyjął, że należności z tytułu składek w znaczny sposób zasilają system ubezpieczeń społecznych i przyczyniają się do unikania zaciągania zobowiązań w celu zapewnienia stałej płynności finansowej poszczególnych funduszy, którymi dysponuje ZUS, jednakże stwierdzenie (skądinąd trafne), że w konsekwencji zapo-

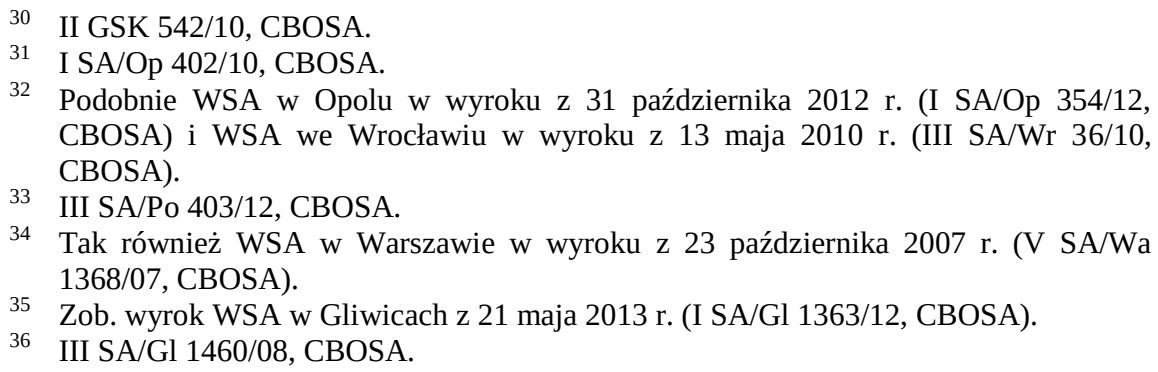


biegają powiększaniu długu publicznego, znacząco wykracza poza dbanie o „stan finansów ubezpieczeń społecznych”.

Nie ma wątpliwości, że począwszy od wejścia w życie reformy ubezpieczeń społecznych (1 stycznia 1999 r.) bezustannie występuje niezadowalający stan finansów ubezpieczeń społecznych, tj. przychody składkowe są niższe niż wydatki na świadczenia ubezpieczeniowe. Gdyby przyjąć, że stosowanie ułatwień w opłacaniu składek nie jest możliwe, gdy stan finansów ubezpieczeń społecznych jest ujemny (np. w skali ro$\mathrm{ku}$ ), to tym samym przepisy dotyczące ułatwień nie znalazłaby w praktyce w ogóle zastosowania. Takie rozumowanie byłoby niewątpliwie sprzeczne ze społeczną funkcją ułatwień w opłacaniu składek. ${ }^{37}$ Zgodzić należy się z tezą wyroku WSA w Gorzowie Wielkopolskim z 14 lipca 2011 r. $^{38}$, że „Skoro ustawodawca wprowadził do systemu prawnego taką instytucję prawną jak dobrodziejstwo umorzenia należności z tytułu składek, to znaczy, że nie może stać się ona jedynie fikcją prawną a przewidujący ją przepis - przepisem martwym,39. NSA w wyroku z 20 marca 2007 r. $^{40}$ wprost wskazał, że ,istnieje ryzyko, że wobec permanentnie niezadowalającego stanu finansów ubezpieczeń społecznych, norma prawna, która dopuszcza umorzenie należności, nie znalazłaby w praktyce w ogóle zastosowania. Takie zaś rozumienie omawianej instytucji byłoby sprzeczne z jej społeczną funkcją".

Interesujący pogląd zaprezentowano w wyroku NSA z 28 kwietnia 2010 r. $^{41}$ : „Zakład musi mieć na względzie stan finansów ubezpieczeń społecznych. Zakład jest dysponentem Funduszu Ubezpieczeń Społecznych, którego przychody pochodzą między innymi z wpłat i z dotacji budżetu państwa. W związku z tym ZUS, dysponując pieniędzmi z budżetu państwa, winien postępować z największą ostrożnością, ważąc z jednej strony interes finansów ubezpieczeń społecznych, a z drugiej uwzględniać ważny interes zobowiązanego. Środki uzyskane przez Zakład z tytułu

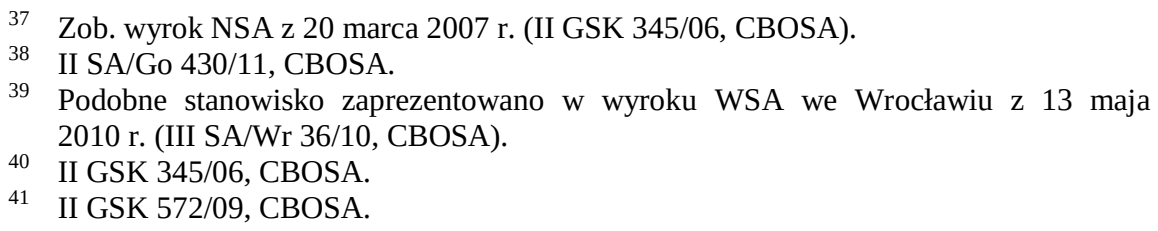


opłaconych składek przeznaczane są bowiem w znacznej części na wypłaty świadczeń społecznych osobom ubezpieczonym, w tym wypłaty rent i emerytur”. Podobnie orzekł WSA we Wrocławiu w wyroku z 24 czerwca 2009 r. $^{42}-$, ,[...] zasadą jest opłacanie składek. Zbyt liberalne stosowanie mechanizmu umorzeń nie pozostawałoby zaś bez wpływu na stan finansów ubezpieczeń społecznych, już i tak nienajlepszy (fakt znany powszechnie)”.

Nasuwa się oczywisty wniosek, że Zakład Ubezpieczeń Społecznych powinien stosować ułatwienia w opłacaniu składek w zależności od tego, jaki jest stan Funduszu Ubezpieczeń Społecznych w ujęciu rocznym. W przypadku występowania niedoboru składek (w stosunku do wydatków), a więc sytuacji, gdy konieczne jest przekazywanie dotacji budżetowej do FUS, Zakład w sposób szczególny winien kierować się „stanem finansów ubezpieczeń społecznych”. Sytuacja odwrotna, a więc nadwyżka składek nad wydatkami ubezpieczeniowymi, umożliwia Zakładowi bardziej „liberalne” stosowanie ułatwień, ponieważ - z uwagi na wystarczającą ilość przychodów w stosunku do wydatków - nie istnieje konieczność sięgania po dotacje budżetowe i nie jest zagrożona płynność finansowa FUS.

Stosowanie ułatwień w opłacaniu składek na ubezpieczenia społeczne nie wpływa w jednakowym stopniu na „stan finansów ubezpieczeń społecznych”. O ile umorzenie składek znacząco wpływa na finanse ubezpieczeń społecznych, o tyle odroczenie terminu płatności czy rozłożenie należności na raty, ma zdecydowanie mniejsze znaczenie.

Umorzenie należności z tytułu składek oznacza, że Zakład w sposób definitywny rezygnuje z określonych przychodów. Umorzone należności z tytułu składek nie zasilą Funduszu Ubezpieczeń Społecznych. Oznacza to, że Zakład Ubezpieczeń Społecznych, wydając pozytywne decyzje w zakresie umorzeń, bezpośrednio zmniejsza przychody Funduszu Ubezpieczeń Społecznych, a pośrednio - powoduje konieczność zwiększenia dotacji z budżetu państwa do FUS.

42 III SA/Wr 685/08, CBOSA. 
W przypadku zastosowania przez Zakład pozostałych ułatwień w opłacaniu składek nie występuje definitywna rezygnacja z przychodów FUS. Odroczenie terminu płatności składek powoduje, że do FUS składki wpłyną, lecz w terminie późniejszym (ustalonym przez Zakład) niż ustawowy. Stosując to ułatwienie, uwzględniając możliwości płatnicze dłużnika, ZUS w znaczący sposób nie wpływa na stan finansów ubezpieczeń społecznych. W literaturze słusznie zatem się wskazuje, że obie przesłanki warunkujące podjęcie przez Zakład pozytywnej decyzji (tj. możliwości płatnicze dłużnika oraz stan finansów ubezpieczeń społecznych) „powinny być uwzględnione łącznie, jednakże nie bez znaczenia pozostaje fakt, że na pierwszym miejscu postawione zostały możliwości płatnicze dłużnika"43.

Podobny skutek wiąże się z rozłożeniem należności z tytułu składek na raty. Zamiast jednorazowej wpłaty, do FUS będzie wpływał określony przychód w comiesięcznych ratach. W ujęciu długoterminowym rozłożenie należności na raty, tak jak odroczenie terminu płatności, nie wpływa negatywnie na stan finansów ubezpieczeń społecznych, zwłaszcza że od składek odroczonych czy rozłożonych na raty płatnik uiszcza opłatę prolongacyjną, która stanowi przychód FUS.

\section{Wnioski}

„Stan finansów ubezpieczeń społecznych”, jako jeden z determinantów stosowania ułatwień w opłacaniu składek na ubezpieczenia społeczne, musi być interpretowany w sposób dynamiczny: w zależności od rodzaju ułatwienia oraz sytuacji finansowej Funduszu Ubezpieczeń Społecznych.

Z uwagi na to, że umorzenie należności z tytułu składek powoduje definitywną rezygnację z części należnych FUS przychodów, odmiennie niż w przypadku odroczenia terminu płatności składek i rozkładania należności na raty, ZUS winien w sposób szczególnie wyważony wydawać pozytywne decyzje w zakresie umorzeń.

43 J. Wantoch-Rekowski [w:] J. Wantoch-Rekowski (red.), Ustawa o systemie ubezpieczeń społecznych. Komentarz, Toruń-Warszawa 2007, s. 223. 
Istotne znaczenie w procesie decyzyjnym ma aktualna sytuacja finansowa FUS - im korzystniejszy stosunek przychodów składkowych do wydatków na świadczenia ubezpieczeniowe, tym ZUS może stosować ułatwienia w sposób bardziej „liberalny”.

\section{Bibliografia:}

Jędrasik-Jankowska I., Pojęcia i konstrukcje prawne ubezpieczenia społecznego, LexisNexis, Warszawa 2010.

Jędrasik-Jankowska I., Ubezpieczenie emerytalne. Trzy filary, Wydawnictwa Prawnicze PWN, Warszawa 2001.

Jędrasik-Jankowska I., Ubezpieczenie społeczne, T. 1, Część ogólna, LexisNexis, Warszawa 2003.

Strusińska-Żukowska J. [w:] B. Gudowska, J. Strusińska-Żukowska (red.), Ustawa o systemie ubezpieczeń społecznych. Komentarz, C.H. Beck, Warszawa 2011.

Uryszek T., Dług Skarbu Państwa jako źródło finansowania deficytu budżetowego, DIFIN, Warszawa 2010.

Wantoch-Rekowski J., Składki na ubezpieczenie emerytalne. Konstrukcja i charakter prawny, TNOiK, Toruń 2005.

Wantoch-Rekowski J., Umarzanie należności z tytułu składek na ubezpieczenia społeczne, „Praca i Zabezpieczenie Społeczne” 2004, nr 3, s. 33-39.

Wantoch-Rekowski J. [w:] J. Wantoch-Rekowski (red.), Ustawa o systemie ubezpieczeń społecznych. Komentarz, TNOiK, Toruń-Warszawa 2007. 